\title{
Assessing the role of civil society in poverty alleviation: A case study of Amathole district in the Eastern Cape province of South Africa
}

\begin{tabular}{|c|c|}
\hline $\begin{array}{l}\text { Authors: } \\
\text { Xolisile G. Ngu } \\
\text { Thozamile R. I }\end{array}$ & $\begin{array}{l}\text { mbela }^{1} \\
\text { Mle }^{2}\end{array}$ \\
\hline $\begin{array}{l}\text { Affiliations: } \\
{ }^{1} \text { Centre for Tra } \\
\text { Studies, Unive } \\
\text { Fort Hare, Eas } \\
\text { South Africa }\end{array}$ & $\begin{array}{l}\text { Insdisciplinary } \\
\text { rsity of } \\
\text { tondon, }\end{array}$ \\
\hline $\begin{array}{l}2 \text { Faculty of Ma } \\
\text { Commerce, Sc } \\
\text { Management } \\
\text { Development, } \\
\text { of Fort Hare, } \\
\text { South Africa }\end{array}$ & $\begin{array}{l}\text { nagement and } \\
\text { hool of Public } \\
\text { and } \\
\text { University } \\
\text { isho, }\end{array}$ \\
\hline $\begin{array}{l}\text { Correspondin } \\
\text { Xolisile Ngumb } \\
\text { xolisile.ngumb }\end{array}$ & $\begin{array}{l}\text { g author: } \\
\text { ela, } \\
\text { ela@gmail.com }\end{array}$ \\
\hline $\begin{array}{l}\text { Dates: } \\
\text { Received: } 08 \text { } \\
\text { Accepted: } 22 \\
\text { Published: } 30\end{array}$ & $\begin{array}{l}\text { eb. } 2018 \\
\text { Mar. } 2019 \\
\text { Sept. } 2019\end{array}$ \\
\hline $\begin{array}{l}\text { How to cite th } \\
\text { Ngumbela, X. } \\
\text { 2019, 'Assessi } \\
\text { civil society in } \\
\text { alleviation: A } \\
\text { Amathole dist } \\
\text { Eastern Cape } \\
\text { South Africa', } \\
\text { Transdisciplin } \\
\text { Southern Afric } \\
\text { https://doi.or } \\
\text { td.v15i1.547 }\end{array}$ & $\begin{array}{l}\text { is article: } \\
\text { j. \& Mle, T.R., } \\
\text { g the role of } \\
\text { poverty } \\
\text { case study of } \\
\text { rict in the } \\
\text { orovince of } \\
\text { The Journal for } \\
\text { ary Research in } \\
\text { a } 15(1), \text { a547. } \\
\text { /10.4102/ }\end{array}$ \\
\hline $\begin{array}{l}\text { Copyright: } \\
\text { (c) 2019. The } \\
\text { Licensee: AOS } \\
\text { is licensed un } \\
\text { Creative Comr } \\
\text { Attribution Lic }\end{array}$ & $\begin{array}{l}\text { uthors. } \\
\text { S. This work } \\
\text { ler the } \\
\text { nons } \\
\text { ense. }\end{array}$ \\
\hline Read online: & \\
\hline 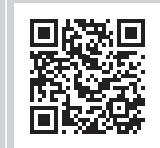 & $\begin{array}{l}\text { Scan this QR } \\
\text { code with your } \\
\text { smart phone or } \\
\text { mobile device } \\
\text { to read online. }\end{array}$ \\
\hline
\end{tabular}

The purpose of this study was to conduct an assessment of the role of civil society organisations (CSOs) in poverty alleviation, with a particular focus on three CSOs operating in the Amathole district of the Eastern Cape province. The CSOs were located in the local municipalities of Amahlathi (Ikhwezi Women Support Centre), Mbhashe (Nyhwarha Home-Based Care) and Mnquma (We Care HIV/AIDS Ministries). A combination of qualitative and quantitative research methods was used. Data were collected from 14 people either working for or associated with the CSOs using semi-structured interviews, structured interviews in which a questionnaire was administered and focus groups. Document analysis supplemented these data collection methods. The findings showed that different interventions by the CSOs played an important role in improving the well-being of community members but that the interventions did not necessarily focus directly on poverty alleviation. Where the CSOs made a direct contribution to poverty eradication, it was done by employing community members in their projects. The challenges that they experienced largely concerned funding and insufficiently skilled human resources. The CSOs were able to plan and monitor their performance, but the logical framework they used failed to prepare them for unexpected changes in their projects. Focused management support from the Department of Social Development will assist the CSOs to become sustainable.

Keywords: Poverty; civil society organisations; poverty eradication; poverty alleviation; strategy.

\section{Introduction}

It is almost two decades since independence from the shackles of apartheid and South Africa is still plunged into a series of challenges, like incessant poverty of the majority of its citizens. Post-apartheid policies and legislation that have been passed seeking to address this catastrophe have long been in place; however, research, and continued violent and non-violent service delivery protests against government institutions by the poor, indicates that progress in eradicating poverty and dealing with racial inequality has been extremely slow and challenging.

While many factors can be blamed for the slow progress in reducing poverty, contradictions in policy and practice within government are part of the problem. The post-apartheid Constitution (Constitution of the Republic of South Africa, Act 108 of 1996), for example, contains clauses that seek to address poverty reduction and other racial inequalities. Section 27 (subsection $1 \mathrm{~b}$ ) of the Constitution states that 'everyone has the right to have access to sufficient food and water' and that 'the state must take reasonable legislative and other measures, within its available resources, to achieve the progressive realization of these rights' (subsection 3). This effectively enshrines food security and poverty reduction as constitutional rights. Section 25 of the Constitution addresses not only land reform but also existing property rights. Through its three components (restitution, redistribution and tenure reform), land reform aims to reverse skewed land distribution, which is the legacy of segregation and apartheid. Its goal is to return land or offer alternative redress to people who unfairly lost their land, make land available for productive and residential purpose to the landless and provide secure land tenure rights where they did not exist. However, these two sections of the Constitution, when taken together, have a complicated relationship. Food security is broadly defined as access by all households at all times to adequate, safe and nutritious food for a healthy and productive life.

Although its more than two decades into democracy, the Eastern Cape province has not been able to run away from the trappings of structural poverty. This is seen in all aspects of its 
demographic, health and socio-economic profiles. Methods, measurements and statistics vary; however, from the various studies and data sets one can estimate that between $20 \%$ and $60 \%$ of the population in the Eastern Cape live in poverty. Table 1 shows the human development index (HDI) ${ }^{1}$ and poverty indictors for all districts, the province and South Africa in 2014 and 2017

As shown in Table 1, the urban, metropolitan municipalities of Buffalo City and Nelson Mandela Bay have the highest HDIs in the Eastern Cape at 0.66 and 0.68, respectively. The Amathole district has a lower HDI at 0.59 but shows an improvement of $0.16 \%$ between 2000 and 2012, indicating that social assistance and public services have had a positive influence on households in the district in the democratic period. While poverty rates declined by $7 \%-24 \%$ between 2000 and 2012 in the Eastern Cape districts, as Table 1 shows, $42.2 \%$ of the provincial population still live in poverty, with a poverty rate of $41.1 \%$ in the Amathole district.

In terms of income, Table 1 shows a wide spatial disparity, with highest incomes in the two metropolitan areas and Cacadu district. Alfred Nzo has the lowest average income, followed by Amathole, Chris Hani and OR Tambo. Apart from Nelson Mandela Bay, all the districts have lower-thannational-average annual income, which shows the marginality of the province in terms of income. According to Baiyegunhi and Fraser's (2014) writing as on the Human Ecology Journal on income, assets and poverty in the Eastern Cape, Amatole district accounts for 26\% of the poverty gap.

As revealed by the percentages shown in Table 1, most people who reside in Amathole district are vulnerable to poverty and the growth of their vulnerability increases the spread of poverty in their societies. Abject poverty is present among the Amathole people, which emanates from illiteracy, unemployment and lack of access to infrastructure, as well as economic and social vulnerability.

South Africa is a largely divided society. People are divided in terms of their class, gender, race and location and their opportunities are, to a large extent, determined by their social position and networks. Social fragmentation manifests itself in various ways, including high levels of domestic violence, substance abuse, criminality, teenage pregnancies, hostility towards people of foreign origin and low levels of mutual respect, social solidarity and other behaviours that reflect a spirit of community, as well as a culture of irresponsibility. High levels of unemployment among youth and women also serve to perpetuate social fragmentation. While these manifestations of social fragmentation occur in all sectors of society, there is a general consensus that they are largely prevalent in those communities that are predominantly poor.

1.The human development index (HDI) provides an indication of human developmen based on life expectancy, health, education and income of a country or region. A ranking of 1 signals a high HDI score and 0 signals a low HDI score.
TABLE 1: Human development index and poverty.

\begin{tabular}{|c|c|c|c|c|}
\hline Variable & 2014 & 2015 & 2016 & 2017 \\
\hline \multicolumn{5}{|l|}{ HDI } \\
\hline Eastern Cape & 0.58 & 0.58 & 0.59 & 0.59 \\
\hline Nelson Mandela Bay & 0.67 & 0.68 & 0.68 & 0.68 \\
\hline Buffalo City & 0.65 & 0.66 & 0.66 & 0.66 \\
\hline Sarah Baartman & 0.61 & 0.62 & 0.62 & 0.63 \\
\hline Amatole & 0.52 & 0.53 & 0.53 & 0.54 \\
\hline Chris Hani & 0.53 & 0.54 & 0.54 & 0.55 \\
\hline Joe Gqabi & 0.53 & 0.54 & 0.55 & 0.55 \\
\hline OR Tambo & 0.50 & 0.51 & 0.51 & 0.52 \\
\hline Alfred Nzo & 0.48 & 0.49 & 0.49 & 0.50 \\
\hline \multicolumn{5}{|c|}{ People below the food poverty line (StatsSA defined) } \\
\hline Eastern Cape & 2153351 & 2198994 & 2508924 & 2600504 \\
\hline Nelson Mandela Bay & 255744 & 261349 & 302311 & 316688 \\
\hline Buffalo City & 176660 & 179433 & 208936 & 217592 \\
\hline Sarah Baartman & 93299 & 97711 & 115514 & 123036 \\
\hline Amatole & 293409 & 296745 & 338476 & 348378 \\
\hline Chris Hani & 255217 & 259844 & 297383 & 307278 \\
\hline Joe Gqabi & 112096 & 114519 & 131679 & 136495 \\
\hline OR Tambo & 592871 & 605897 & 683423 & 705526 \\
\hline Alfred Nzo & 374960 & 384413 & 432260 & 446610 \\
\hline \multicolumn{5}{|c|}{ Share below the food poverty line (StatsSA defined) } \\
\hline Eastern Cape (\%) & 31.4 & 31.7 & 35.8 & 36.7 \\
\hline Nelson Mandela Bay (\%) & 20.9 & 21.0 & 23.9 & 24.7 \\
\hline Buffalo City (\%) & 22.0 & 22.1 & 25.4 & 26.1 \\
\hline Sarah Baartman (\%) & 19.5 & 20.1 & 23.4 & 24.5 \\
\hline Amatole $(\%)$ & 32.7 & 33.0 & 37.5 & 38.5 \\
\hline Chris Hani (\%) & 31.3 & 31.6 & 35.8 & 36.7 \\
\hline Joe Gqabi (\%) & 30.7 & 31.0 & 35.2 & 36.1 \\
\hline OR Tambo (\%) & 41.3 & 41.7 & 46.5 & 47.4 \\
\hline Alfred Nzo (\%) & 44.9 & 45.6 & 50.7 & 51.8 \\
\hline
\end{tabular}

Source: United Nations Development Programme (UNDP), 2019, Human Development Indices and Indicators: 2018 Statistical Update, United Nations Development Programme, New York, NY

HDI, human development index; StatsSA, Statistics South Africa.

\section{Demographic information Population \\ Population pyramid}

In 2017, it was estimated that 6.5 million people are residing in the province, where $52.8 \%$ (3.4 million) were men and $47.2 \%$ (3.1 million) were women. The population of the province constitutes $11.5 \%$ of the South African population (Figure 1).

The Eastern Cape province is predominantly composed of the young people. These estimates show that $40.1 \%$ of the population are between the age of 15 and 34 years. This has significant implications about the provision of basic health services (e.g. health and education) for these young people.

Access to food in most of the households remains one of the serious challenges in the province. Some of the contributing factors relate to socio-economic status, such as lack of job opportunities and low levels of education (Figure 2).

Access to water for household use is one of the developmental indicators that has significant impact on the health status of the population. 


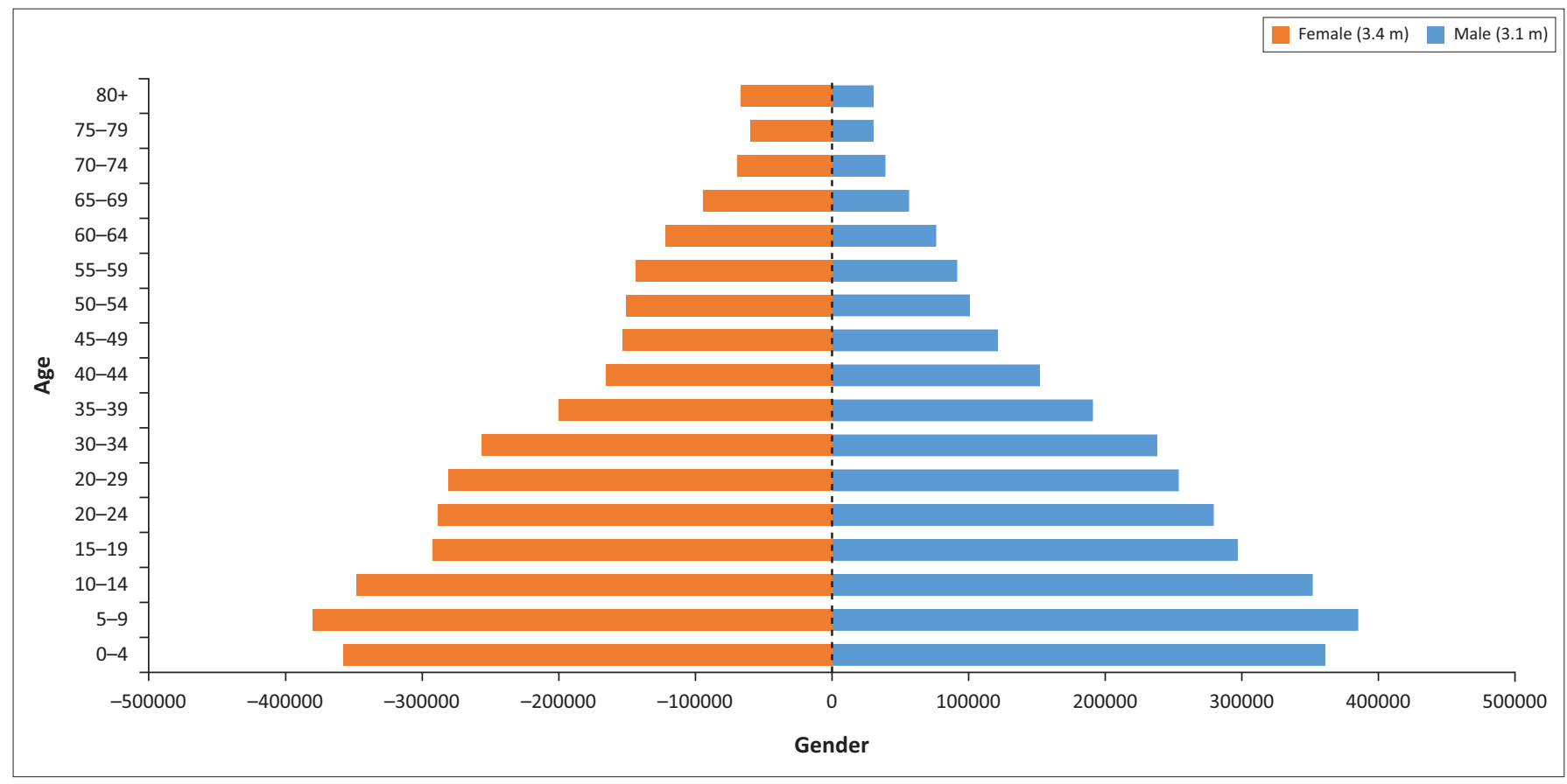

Source: Statistics South Africa (StatsSA), 2016, Statistical Release P0301: Community Survey 2016, Statistics South Africa, Pretoria FIGURE 1: The 2017 population pyramid ( $N=6.5$ million).

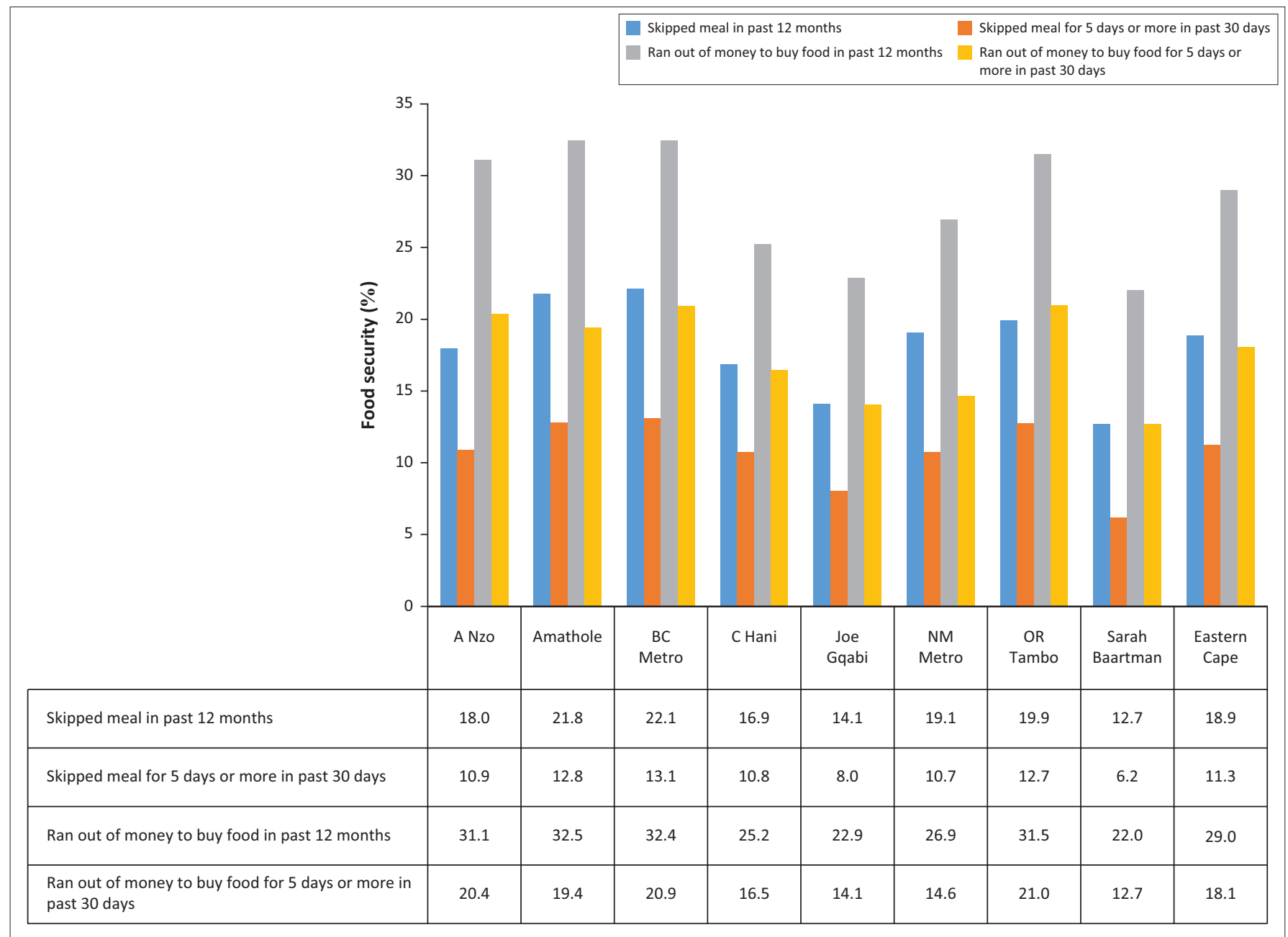

Source: Eastern Cape Socio Economic Consultative Council (ECSECC) and Quantec, 2016, 2015/2016 Annual Report, viewed n.d., from https://www.ecsecc.org/documentrepository/ informationcentre/annual-report_30560.pdf

A Nzo, Alfred Nzo; BC Metro, Buffalo City Metro; C Hani, Chris Hani; NM Metro, Nelson Mandela Bay Metro; E Cape, Eastern Cape.

FIGURE 2: Food security indicators for the Eastern Cape, 2016. 
From 2009 to 2013, access to piped water by households increased from $74.7 \%$ to $80.5 \%$. However, there is a noted decline from 80.5\% in 2013 to $75.7 \%$ in 2016 (Figure 3).

\section{Water sources by district}

Figure 4 shows that $73.6 \%$ of the households in the Eastern Cape province have access to piped water. More than $90 \%$ of the households from Buffalo City Metro, Nelson Mandela Metro and Sarah Baartman had access to piped water, with low percentage of those households using unsafe water sources.

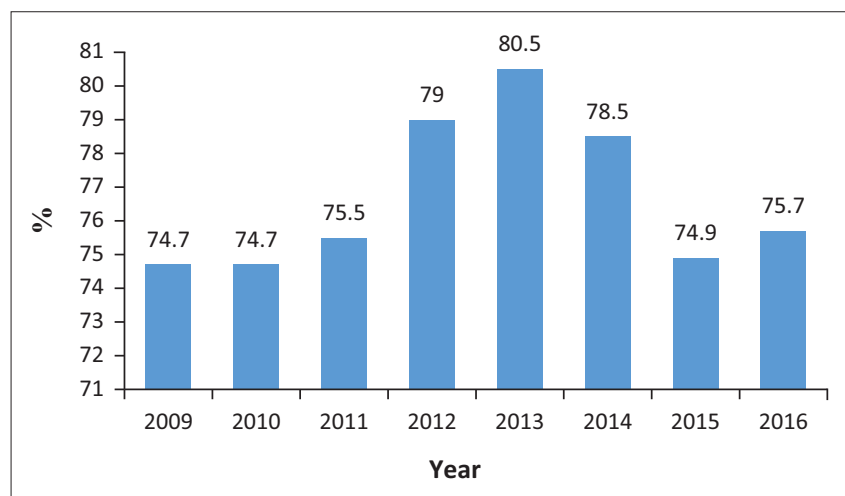

Source: Statistics South Africa (StatsSA), 2016, Statistical Release P0301: Community Surve 2016, Statistics South Africa, Pretoria

FIGURE 3: Per cent of households with access to piped water in Eastern Cape province, 2009-2016.
However, $25 \%$ of the households still get water for household use from unsafe water supplies like rivers, streams, wells and springs. The lowest access to piped water was seen in Alfred Nzo and OR Tambo, with more than $50 \%$ of their households getting water from unsafe water supplies.

In response to the high rates of poverty across the country, the government has developed several anti-poverty measures, with social grants as the most important measure. Social grants have contributed to poverty reduction in the Eastern Cape province, as shown in Table 1. Households often survive on old age and child support grants if there is no other income. In 2012, a total of 2655831 beneficiaries in the Eastern Cape received social grants. The province has the highest percentage of people receiving social grants, at $40.5 \%$, compared to the national average of $30 \%$.

While grants have a positive impact, there is a need to couple social assistance with access to basic services and other public social services, and to create jobs for sustained impact over time. For this reason, other government anti-poverty measures include economic interventions to expand opportunities for employment, and self-employment in particular, to provide community- and public-works programmes, to provide quality education and skills and healthcare, to promote access to assets including social capital, and to promote social cohesion.

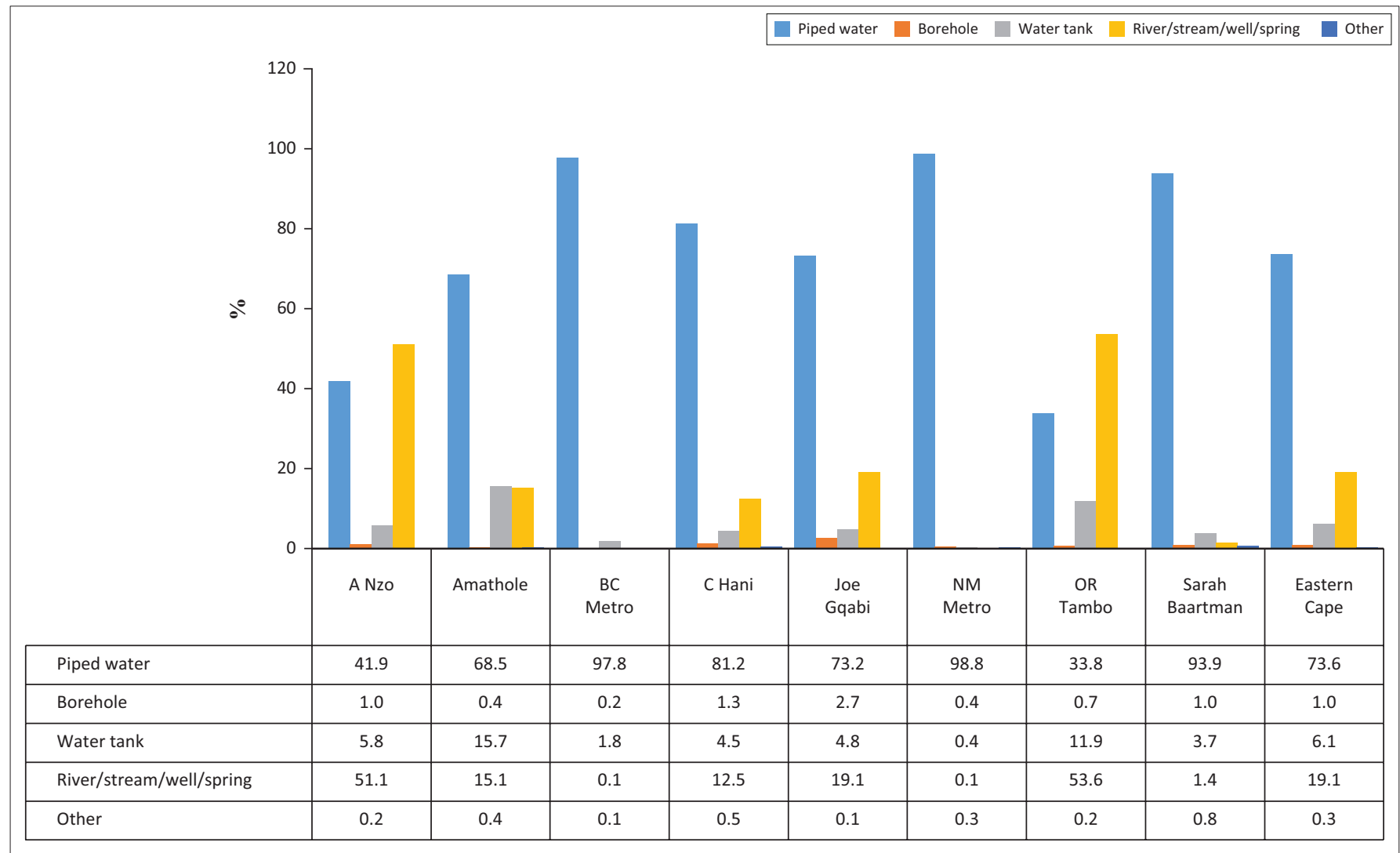

Source: Statistics South Africa (StatsSA), 2016, Statistical Release P0301: Community Survey 2016, Statistics South Africa, Pretoria A Nzo, Alfred Nzo; BC Metro, Buffalo City Metro; C Hani, Chris Hani; NM Metro, Nelson Mandela Bay Metro; E Cape, Eastern Cape. FIGURE 4: Water sources for use by households in the Eastern Cape province, 2016. 
An example of an anti-poverty measure that operates in the Eastern Cape is the Anti-Poverty Strategy of 2012. This strategy emanated from the Eastern Cape's Provincial Growth and Development Plan (PGDP), which was developed for 2004-2014, which highlighted 'poverty eradication' as a priority and gave the Department of Social Development the responsibility of coordinating and launching the 'war on poverty' from 2006. The Anti-Poverty Strategy used the strengths and opportunities that emanated from the experiences of both the government and civil society, with strategic goals to:

1. eradicate extreme poverty and hunger;

2. promote sustainable community livelihoods and selfreliant households; and

3. ensure well targeted, joined-up implementation and service delivery by government and its social partners. (Eastern Cape Provincial Anti-Poverty Strategy 2012:8)

In line with the goals of the Anti-Poverty Strategy, both the Departments of Social Development and Health have funded a large number of sustainable livelihood projects and youth development projects within the Amathole District Municipality. While most of the civil society organisations (CSOs) involved in these projects are reportedly doing well, some are reported to be struggling to remain afloat using the grant contracts entered into between the CSOs and the government departments funding them. Other reports are that these organisations face challenges as a result of poor alignment within the municipalities' strategic plans or integrated development plans, that there is no coordination and proper mapping of these organisations, that they are poorly managed, and that government monitoring and evaluation of these organisations within their jurisdictions is not visible.

In light of these reported problems, this study aimed to assess the role of CSOs in poverty eradication strategies in the Amathole District Municipality and to establish the challenges and obstacles faced by state interventions with respect to poverty alleviation. On the basis of these findings, a third aim was to suggest remedial action to promote poverty alleviation strategies in the municipality. This study is an attempt to contribute to the debate about the important role of civil society in poverty alleviation strategies in the local government setting.

\section{Definitions of poverty}

The definition of poverty is important for the development of this article's argument on fighting food insecurity. Definitions, and thus the measurement, of poverty are subject to debate and academic study. The Studies in Poverty and Inequality Institute (SPII 2007:31) argues that one can adopt 'more than one' definition of poverty, as different definitions and their associated measures focus attention on and quantify different aspects or dimensions of poverty. Both international and South African literature and policy documents highlight the fact that the key elements of poverty are economic, social and spatial issues. This article recognises the multidimensional nature of poverty and seeks to address the distinct challenges of the geo-space of the province.

The 2008 Eastern Cape Poverty Summit adopted the following definition of poverty:

Poverty is defined as an inability of individuals, households or communities to command sufficient resources to satisfy a socially acceptable minimum standard of living. It is more than merely income insufficiency. It includes lack of opportunity, lack of access to assets as well as social exclusion. (p.14)

Taking cognisance of the Eastern Cape province's conceptualisation in addressing poverty, inequality and its various social manifestations, not only technical planning and delivery solutions but also a process of mobilisation and conscientisation of all in society is required.

The definitions of and discourses around poverty are 'multifarious and highly extensive;' however, the concept 'poverty' is commonly used to refer to the absence of the basic necessities of life, such as income, good health, education, security and self-confidence (Emmanuel 2012:43). According to Sen $(1992,2001)$ as quoted by Van der Berg (2010:1), poverty is not only the absence of financial resources but also the insufficient capability to function in society. Sen's definition broadens the comprehension of the concept of poverty as a condition that results in a deficiency of freedom to choose, which arises from a lack of capability to choose and function effectively in one's society.

Within the international context, poverty is often defined in terms of monetary income (viewed from 23 March 2015, www.westerncape.gov.za capegateway.gov.za). Following this definition, poor people are those who fall below an income threshold and/or a particular amount of expenditure that is necessary for consumption purposes. However, within the South African context, poverty is viewed from the broader perspective as the denial of opportunities and choices that are assumed to be essential for human development. These are the opportunities and choices that result in a long life that is characterised by the feeling of being healthy and creative and that provide one with the opportunity to enjoy a decent standard of living, 'freedom, dignity, self-esteem and respect from others' (Statistics South Africa [StatsSA] 2009).

The Poverty and Inequality Report prepared for the Presidency in 1998 describes poverty as a sense of alienation from one's community, 'food insecurity, crowded homes, usage of unsafe and inefficient forms of energy, lack of adequately paid and secure jobs and fragmentation of the family' (Poverty and Inequality Report for the Presidency 1998). All of these definitions were used in the consideration of poverty in this study.

\section{Civil society organisations}

Poverty alleviation and its eventual elimination are the main objective of development. Matenga (2001) argues that 
governments alone are not managing to cater for the welfare of their people. In pursuit of developmental solutions to developmental problems besetting the African continent, the international donor community increasingly regards CSOs as an important partner in empowering people in their quest for efficient, effective and sustainable developmental services.

The term 'civil society' refers to a diversity of interest groups that are created for a specific purpose. These interest groups could be ratepayers' associations, farmers' associations, civic associations, non-governmental organisations (NGOs) or community-based organisations (CBOs), among others (Craythorne 2003 cited in Mavee \& Cloete 2011:65). For the purpose of this discussion, the term 'civil society' is used interchangeably with CSOs as interest groups are a form of organisation.

Civil society may be viewed as a space that exists between government and its citizens (Prestegard 2005:24). In other words, civil society symbolises a collaboration of the intermediary groupings that operate within the social and political space between (1) the primary units of society (individuals, families [nuclear and extended] and village units) and (2) the government and its agencies (Mavee \& Cloete 2011:68, 69). Civil society organisations coordinate collaboration between the government and citizens. On the contrary, as much as they create this collaboration, their priority is to represent the interests of the citizens.

Civil society organisations have a huge role to play in campaigns of poverty alleviation. Their value lies in the fact that they mobilise people to participate in strategic plans and diverse activities of government while fighting against poverty. Mavee and Cloete $(2011: 68,69)$ state that CSOs organise people to form powerful groups as a means of influencing public policies by becoming active participants in policy formulation and implementation. CSOs also organise people to make public resources accessible to the people (especially underprivileged people), rather than being monopolised by government officers. This makes the contribution of CSOs important to the ordinary citizens of a nation.

While civil society plays an important role in poverty alleviation, it has its own challenges. Firstly, CSOs tend to compete for donor funds even where they operate in the same space and with the same purpose (Mavee \& Cloete 2011:68, 69). According to Prestegard (2005:30), those with more organisational resources (e.g. large NGOs) stand better chances of establishing contacts with potential funders and maximising their opportunities to receive funding. Such a situation could lead to the development of the already established CSOs, while smaller ones remain underdeveloped and under-resourced.

Secondly, as Prestegard (2005:28, 29) points out, while development discourse often portrays the civil society sphere as working in consensus, in fact, this sphere is characterised by power relations, inequality and conflict. Civil society constitutes a diversity of interest groups. This diversity of interests inhibits a civil society from achieving its common purpose, which is poverty alleviation in this instance.

The Millennium Development Goals Country Report of 2010 states that the majority of South Africans are still living under unequal and poverty-stricken conditions despite a series of poverty alleviation strategies employed by the South African government in partnership with organised civil societies. This makes the assessment of the role of CSOs in poverty alleviation important.

\section{Land and food security}

As the focus of this article is to critically appraise the role of CSOs in poverty alleviation, it is imperative to revisit the issue of land and food security. From the data presented in this article so far, it is clear that the respondents are almost entirely dependent on grants from the government's social assistance programme to complement their low salaries. Little or no interest is shown in agriculture or small household food gardens.

A debate on land should not only concentrate on sustainable livelihoods and reduced poverty and inequality, but also relate to the production of food and land redistribution for agricultural development. High food prices because of the incessant provincial drought are seriously worsening the living standards of workers and the poor and are thus a major cause of concern. The main issue for the province is land lying fallow vis-à-vis food production. The disregard of land reform is a key contributor to increases in food prices, among other imperatives. Fields that used to produce plenty of food are now lying fallow. Hence, the vast majority of poor people and rural communities are still trapped in poverty, hunger and starvation, especially in the eastern part of the province.

However, land ownership does not necessarily mean one will become food-secured. This is because of the noted lack, or unavailability, of household food gardens. It has generally been agreed that the pace of the rollout of the land reform programme, on which the realisation of land as a right and a resource rests, has been very slow. A mere 3\% of the land had been transferred into black African hands by 2004 (Ntsebeza 2006), a far cry from government's own targets and people's expectations (Hall \& Chennels 2011). Ntsebeza outlines two streams of thought that seek to understand this slow pace: one argument has it that the necessary policies are in place, but lack of political will is frustrating the process. The other argument points to the fact that there are problems with the policy itself,

[I]n particular the entrenchment of the property clause (protection of existing rights in particular) in the Constitution, as well as the endorsement in the policy of the 'willing buyer, willing seller' principle. (Section 25 of the Bill of Rights of Our Constitution) 
Ntsebeza further endorses the latter argument as a key contributor to the slow pace and argues that even the Expropriation Act, which is embedded in the existing land reform policy, has made very little impact, given that it weighs heavily in favour of land-owning white commercial farming interests, and uses a formula that allows the market to determine the amount of compensation. Ntsebeza's argument suggests that, in view of the plethora of landrelated needs, the overall land reform programme will continue at a snail's pace if these issues are not openly debated and addressed. Of particular concern is the land redistribution programme and its sub-programmes, which potentially limit the development of other sectors of the economy; however, the lack of progress with regard to the restitution and tenure reform pillars are similarly causes for concern.

As a way forward, this research study proposes that serious note should be taken of the following:

- There is an urgent need for clarity on who owns the land, and the suitability thereof, for productive uses in order to make land available to all those who might need it for farming.

- Communities should be consulted and agree on how land should be utilised, particularly land that is lying fallow.

- The state should play a regulatory role in ensuring that land is not underutilised.

- In cases where land is insufficient for food security and there are clear signs of members of the community being interested in working the land for food production, land should be made available through land reform programmes.

- The state needs to support agricultural institutions, both to encourage agricultural entrepreneurship and to benefit those farmers who are without formal education.

- The state should step up its agrarian reform programmes to support productive utilisation of the land. Agricultural extension officers must be made available and should be based in the local municipalities, rather than in head offices or boardrooms, and should be assisted by the Department of Social Development in profiling poor households who should be priorities in these programmes.

- The state should ensure participation of producers in the market through incentive schemes and not let the markets be an end-to-all, determining prices without taking into consideration the means of productions and the salaries in the country.

This study strongly considers the twin issues outlined above in its approach, namely, land as a right and land as a resource, if we are serious about addressing the question of land and food security for the downtrodden of our country.

\section{Methodology}

The study was conducted on three CSOs that had been contracted by the Department of Social Development to carry out poverty alleviation projects in the Amathole District Municipal area of the Eastern Cape province. These CSOs were chosen as the study sample using a purposive sampling method. They were the Ikhwezi Women Support Centre, which operated in the Amahlathi Local Municipality; Nyhwarha Home-Based Care, which operated in the Mbhashe Local Municipality; and We Care HIV/AIDS Ministries, which operated in the Mnquma Local Municipality. A total of 14 people who occupied different job positions in these CSOs or were associated with the CSOs were selected as study participants. The participants comprised board members, care givers, community development workers and a project manager. A client of one of the CSOs was also interviewed.

The study used a combination of qualitative and quantitative research methods. Data were collected through semistructured face-to-face interviews. Each interview lasted for $45 \mathrm{~min}$ and was conducted in the mother tongue (isiXhosa) of the research participants to facilitate the collection of as much information as possible. The data collected were translated into English as the researcher wrote up field notes. Structured interviews were also conducted in which the participants were supplied with a questionnaire to answer and given standardised instructions on how to fill it in.

Focus group interviews were conducted as a way of encouraging participants' views on topics of interest to the researcher. The researcher sensitised the focus group members to respect the confidentiality of the other participants' views and information shared during the session. The researcher used a structured open-ended set of questions that was posed to the participants to guide and facilitate a free-flowing process in which participants felt free to air and share their opinions without being interrupted by the researcher.

Document analysis supplemented the other data collection methods. Annual reports, quarterly performance reports, monthly reports, minutes of meetings and the financial reports of the selected CSOs and the Department of Social Development were scrutinised. These sources of evidence were used to provide more information and points of clarity that might not have been properly captured during the faceto-face interviews or during the focus group sessions.

\section{Ethical consideration}

Ethical clearance was obtained from the University of Fort Hare Research Centre (Mle071SNGU01).

\section{Results and discussion Types of intervention conducted by the civil society organisations}

The findings of this study revealed that the CSOs played an important role in making improvements to the general wellbeing of people at community level but that their areas of intervention were not necessarily focused directly on poverty 
alleviation strategies. The CSOs worked in four areas: genderbased violence, community or home-based care, health awareness campaigns and education, and income generation. Any poverty alleviation initiatives undertaken by these CSOs formed part of their projects - for instance, combining an HIV and AIDS project with a job creation project to support people living with HIV and AIDS.

The goals of the CSOs that dealt with gender-based violence were to provide counselling and paralegal support to women and girls who had experienced this type of violence or lived with HIV and/or AIDS, to empower organisations and community members to get involved in programmes to address aspects of gender-based violence and HIV and AIDS, and to lobby for policy change on women's issues related to gender-based violence and HIV and AIDS. A further goal was to ensure that women and girls received effective assistance from the police and judiciary.

The goals of the projects that dealt with home-based or community care were to provide home-based care to the sick; to run community-based support centres to help people living with HIV and AIDS, disabled people, orphans, people with social problems and people with Tuberculosis (TB) and chronic illnesses; and to identify and provide psychosocial support for child-headed families, orphans and vulnerable community members.

The health awareness and education campaigns of the CSOs aimed to improve the health status of community members by encouraging them to adhere to the treatment for HIV and AIDS and TB and to improve the health awareness and awareness about issues concerned with gender-based violence and HIV and AIDS. The CSOs worked to collaborate with government and private-sector stakeholders on the implementation of ongoing education and awareness programmes to combat ignorance and discrimination in the broader community and the workplace. A last aim was to work in partnership with and promote organisations involved in community-based HIV and AIDS initiative and advocacy.

The CSOs had goals for the establishment of income generation projects as a way of fighting poverty for their intended beneficiaries - people living with HIV and AIDS and community members - and the creation of job opportunities for unemployed community members.

From the above discussion, it is clear that some of the objectives of the CSOs addressed the basic living conditions of the intended beneficiaries, particularly underprivileged people. Within the South African context, poverty alleviation strategies need to address the basic needs of local people, create opportunities for self-employment, develop human resources and skills, and ensure that people live in an environment that is safe and secure (Ababio \& Meyer 2012:7). In this way, it can be said that the CSOs indirectly contribute to poverty alleviation.

\section{Poverty eradication strategies}

The findings of this study indicate that the CSOs made a direct contribution to poverty eradication through the creation of employment opportunities. The three organisations observed created employment opportunities for 331 people, although most of the people (64\%) were employed on a part-time basis. The creation of job opportunities took place in addition to the purpose of providing assistance to their beneficiaries held by some organisations, which involved them in diverse methods of alleviating poverty.

Some of these methods were:

- Educating beneficiaries (of the interventions) on how to plough vegetables in their gardens. Adopting this approach would provide them with necessary skills and the knowledge regarding how to take care of their gardens and thus assist in alleviating poverty at the community level.

- Mobilising community members to become engaged in income generation projects, which included poultry farming, sewing and gardening. The intended beneficiaries were HIV-positive people and those affected by HIV and AIDS.

- Creating employment by making use of the government's expanded public-works programmes and food projects from the vegetable gardens.

- Establishing cooperative projects for women in rural communities.

- Facilitating community participation in development projects.

- Facilitating the establishment of various poverty alleviation projects within the identified communities.

Mavee and Cloete (2011) argue that CSOs play a vital role in organising people to form influential groups. The value of these groups lies in the fact that they become the means of influencing public policies in order to pursue the interests of ordinary community members. They do this by participating in policy formulation and implementation, while organising people to make public resources accessible to the people. Moreover, government and CSOs work together to assess the needs of the intended beneficiaries as a precondition for the effective implementation of programmes.

\section{Challenges experienced by the civil society organisations}

The insufficiency of funding was one of the key challenges that was highlighted by the CSOs. Insufficient funding inhibited the CSOs from executing their activities optimally. As Prestegard (2005:30) reports, CSOs tend to compete with each other for donor funds, which results in competition between them rather than collaboration. Inadequate collaboration minimises the chance of CSOs working as a team towards solving societal problems.

A second challenge was that the human resources of these organisations did not have the knowledge and skills 
necessary for effectively conducting the duties and executing the activities of the organisations. The strength of an organisation is determined by its human resources. Without well-trained staff, an organisation has to rely on the services of outside expert consultants. This is a disadvantage to such an organisation as it has to spend financial resources on consultants, which could have been spent on other projects.

A third challenge is that insufficient knowledge and skills on the part of an organisation's human resources means that such an organisation is unable to deal with project implementation complexities.

A fourth challenge was the problem of high defaulter rates for organisations that provided treatment to patients living with HIV and AIDS. This situation was attributed to several challenges, such as healthcare facilities located far away from the residential areas of patients and poverty that made it difficult for patients to consume medication on empty stomachs. The manifestation of high levels of defaulter rates indicates that an intervention is not being delivered adequately to the intended beneficiaries. Babbie and Mouton (2001:374) discuss the concept 'coverage', which is defined as the extent to which participation by intended beneficiaries achieves the levels specified in programme design. In other words, the delivery of the services ought to take place as specified in the plans of the intervention and beneficiaries should receive the service as intended.

\section{Tools used by the civil society organisations}

The findings of the study revealed that among the tools that were used regularly by the CSOs was the Logical Framework Analysis (LFA). The LFA is a graphical presentation of how a programme's objectives and activities fit together to produce the desired outcomes. It is a tool that is used to create congruence between what has been planned and what was actually done (Vingilis \& State 2011). This means that it is a tool that can be used in executing performance assessment and planning at the same time.

The LFA tool has some disadvantages, however. It can lead planners of development projects to believe that there is a direct link between the concepts presented in plans and the way in which these plans are realised (Cernea 2006:46). In other words, they expect to achieve the intended outcomes in terms of their plans. The adoption of such an approach is not realistic because the relationship between inputs and outputs is not linear; the responses as a result of certain inputs are sometimes non-proportional. It is necessary, therefore, for these organisations to plan for the unexpected changes that arise as a consequence of their activities.

Additional tools that were used were from the Department of Social Development, the Department of Trade and Industry and the Department of Health. These tools included attendance registers, referral systems, leave forms, contracts of employment and evaluation forms.

\section{Performance management}

Food security was disclosed as one of the sector programmes or projects of focus by the CSOs. In relation to the goal of providing food security to beneficiaries, one of the organisations reported two indicators of success in their efforts towards poverty alleviation:

- the existence of the food security garden project in the community of beneficiaries, on the premises of the local hospital as a manifestation of the output of the intervention

- a positive response from the beneficiaries of the intervention, that is, a diversity of community members confirmed that they were receiving fresh vegetables from the project.

Among the objectives raised by the CSOs was, firstly, to make improvements to the health status of community members by encouraging them to adhere to their treatment for HIV and AIDS and TB and, secondly, to conduct health awareness campaigns as part of improving the health status of community members, especially with regard to HIV and AIDS and TB. The indicator of success with regard to these objectives was the manifestation of positive changes among the intended beneficiaries of the interventions, in other words, the community members that were infected by HIV. The organisation's clients (beneficiaries) that were HIV-positive were complying with their HIV treatments and consequently there were many cases of improvements in their health status.

Unfortunately, adherence to treatment was undermined by the challenge of poverty in many households in the communities. There were many instances where individual community members did not have the food required to be taken before HIV medication. Such a situation inhibited the chances of treatment adherence by clients.

The study found that hosting health awareness campaigns was also an appropriate example of outputs. The question that needs to follow is 'do the outputs result in a positive change for the intended beneficiaries?' In this instance: 'does hosting health awareness campaigns result in compliance with HIV treatments by HIV-positive clients?' If the answer is 'yes', the implication is that the outputs lead to the intended outcomes.

It is a common phenomenon that CSOs host workshops for their employees with the aim of capacitating them with the knowledge about a particular area. Interestingly, while ongoing workshops take place, it appears that these employees remain without that knowledge. In terms of measuring performance, the organisations would count the workshops as indicators of success with regard to their performance, even if the workshops (outputs) did not lead to gained knowledge (outcomes) about that particular subject. This suggests that CSOs must make efforts to gain a better understanding of performance measures as a part of making improvements to their performance. 


\section{Conclusion}

The contribution of the CSOs to the welfare of the communities in which they work is indispensable. The findings of the study revealed the interventions executed by the CSOs to be interventions on issues of gender-based violence, community or home-based care, health awareness campaigns and education, and income generation. Civil society organisations were found to contribute by creating opportunities for selfemployment, addressing food security issues and raising awareness regarding health and safety issues.

Civil society organisations also have an essential role to play with regard to mitigating the challenge of poverty in communities by creating employment opportunities and providing food security for impoverished communities.

The challenges that CSOs face include insufficient funding as a necessary resource for executing the activities of the organisations and insufficient knowledge and skills of the human resources of the CSOs.

Civil society organisations use the LFA tool to plan and monitor their projects. This is a useful tool in that it provides a graphic presentation about the diverse components of an intervention, such as the relationship between an intervention's objectives, activities and intended outcomes. However, the LFA encourages planners to treat projects as predictable and does not prepare them to encounter unexpected changes as implementation of the projects takes place.

In light of the usefulness of CSOs in supplementing government's poverty eradication strategies, it would be useful for the Department of Social Development to attend to the challenges faced by the CSOs, for example, by putting financial management controls and record-keeping systems in place.

\section{Acknowledgements}

The authors would like to thank the civil society organisations that provided data for analysis.

\section{Competing interests}

The authors have declared that no competing interests exist.

\section{Author's contributions}

T.R.M. was the supervisor of X.G.N. (student) at the University of Fort Hare, Bhisho Campus.

\section{Funding}

This research received no specific grant from any funding agency in the public, commercial or not-for-profit sectors.

\section{Data availability statement}

Data sharing is not applicable to this article as no new data were created or analysed in this study.

\section{Disclaimer}

The views and opinions expressed in this article are those of the authors and do not necessarily reflect the official policy or position of any affiliated agency of the authors.

\section{References}

Ababio, E.P. \& Meyer, D.F., 2012, 'Local Economic Development (LED): Building blocks, strategy and implementation for local government in South Africa', Administratio Publica 20(4), 6-27.

Babbie, E. \& Mouton, J., 2001, The practice of social research, Oxford University Press Southern Africa, Cape Town.

Baiyegunhi, L.J.S. \& Fraser, G.C.G., 2014, 'Poverty Incidence among smallholder in farmers in the Amathole', Journal of Human Ecology 46(3), 261-273.

Bussey, E., 2005, 'Constitutional dialogue in Uganda', Journal of African Law 49(1), 1-23. https://doi.org/10.1017/S0021855305000021

Casley, D. \& Kumas, K., 1984, Monitoring and evaluation public sector and rural development management, Macmillan, Rome.

Cernea, R.F., 2006, The great Latke-Hamantash debate, University of Chicago Press, Chicago, IL.

Eastern Cape Provincial Growth and Development Plan, 2004-2014, viewed 27 August 2014, from http://www.ecdc.co.za/files/documents/110608162407.pdf.

Eastern Cape Socio Economic Consultative Council (ECSECC) and Quantec, 2016, 2015/2016 Annual Report, viewed n.d., from https://www.ecsecc.org/ documentrepository/informationcentre/annual-report_30560.pdf

Emmanuel, A.A., 2012, 'Poverty alleviation strategies by non-profit organisations: Benefactors' experience in the riverine area of Ondo State, Nigeria', International Journal of Developing Societies 1(2), 43-52. https://doi.org/10.11634/ 21681783150486

Ferguson, J., 1994, 'Development and bureaucratic power in Lesotho', The Ecologist 24(5), 18-25.

Hall, K. \& Chennels, M., 2011, Children and poverty: A brief update, Children's Institute, University of Cape Town, Cape Town.

May, J., 1998, Experience and perceptions of poverty in South Africa, Final Report, Praxis Publishing, Durban.

Matenga, C.R., 2001, Africa insight, Issue 1, Africa Institute of South Africa, Pretoria.

Mavee, S.E.A. \& Cloete, F., 2011, 'The role of civil society organisations in the policymaking process in Mozambique. Case study of the poverty reduction strategy paper,' Administratio Publica 20(4), 64-83.

Ngwane, A.K., Yada Valli, V.S.S. \& Steffens, F.E., 2001a, 'Poverty in South Africa in 1995 - A totally fuzzy and relative approach', Journal for Studies in Economics and Econometrics 25(1), 77-87.

Ngwane, A.K., May, J., Jonah, C., Nguyen, N., Sulla, V., Khan, S. et al., 2001, Poverty and inequality report for the presidency, 1998, Government Printers, Pretoria.

Ntsebeza, L., 2006, Democracy compromised: Chiefs and the politics of the land in South Africa, HSRC Press, Pretoria.

Prestegard, L., 2005, 'Depoliticising poverty reduction? Civil society participation in the formulation of the Zambian PRSP', Cand. Polit thesis, Department of Political Science, University of Oslo.

Statistics South Africa (StatsSA), 2016, Statistical Release P0301: Community Survey 2016, Statistics South Africa, Pretoria.

Statistics South Africa (StatsSA), 2009, Twenty-third edition of Statistics South Africa, Statistics South Africa, Pretoria.

Studies in Poverty and Inequality Institute (SPII), 2007, The measurement of poverty in South Africa project: Key issues, Richmond, Johannesburg.

Van der Berg, S., 2010, Poverty and education, The International Institute for Educational Planning (IIEP), Paris, France.

Tafira, H.K., 2018, Black Nationalist thought in South Africa: The persistence of an idea of liberation, Springer.

Vingilis, E.R. and State, S.A. 2011, Applied research and evaluation in community mental health services: An update of key research domains, McGill-Queen's University Press, Montreal.

United Nations Development Programme (UNDP), 2019, Human Development Indices and Indicators: 2018 Statistical Update, United Nations Development Programme, New York, NY. 